\title{
Diagnostic methods to cutaneous leishmaniasis detection in domestic dogs and cats*
}

\author{
Daliah Alves Coelho Trevisan ${ }^{1}$ \\ Izabel Galhardo Demarchi ${ }^{1}$
}

\author{
Maria Valdrinez Campana Lonardoni ${ }^{1}$
}

DOI: http:/ /dx.doi.org/10.1590/abd1806-4841.20153716

\begin{abstract}
Cutaneous leishmaniasis is caused by different species of Leishmania. In domestic animals such as dogs and cats, the diagnostic consists of clinical, epidemiological and serological tests, which changes among countries all around the world. Because of this diversity in the methods selected, we propose this systematic literature review to identify the methods of laboratory diagnosis used to detect cutaneous leishmaniasis in domestic dogs and cats in the Americas. Articles published in the last 5 years were searched in PubMed, ISI Web of Science, LILACS and Scielo, and we selected 10 papers about cutaneous leishmaniasis in dogs and cats in the Americas. In Brazil, often the indirect immunofluorescence and enzyme immunoassay (ELISA) have been applied. Other countries like United States and Mexico have been using antigenic fractions for antibodies detections by Western blot. ELISA and Western blot showed a higher sensitivity and efficacy in the detection of leishmaniasis. Analysis of sensibility and specificity of the methods was rarely used. Although confirmatory to leishmaniasis, direct methods for parasites detection and polymerase chain reaction showed low positivity in disease detection. We suggested that more than one method should be used for the detection of feline and canine leishmaniasis. Serological methods such as Western blot and enzyme immunoassay have a high efficacy in the diagnosis of this disease.
\end{abstract}

Keywords: Americas; Leishmania; Leishmaniasis, cutaneous; Sensitivity and specificity;

\section{INTRODUCTION}

American cutaneous leishmaniasis (ACL) is caused by protozoa of the genus Leishmania. The parasite transmission cycle occurs between a phlebotomine sandfly (vector) and wild animals. Men and domestic animals such as dogs and cats can become infected when penetrating in this ecosystem. The infection is characterized by lesions of skin and mucous membranes. ${ }^{1}$

Currently there are 21 known species of Leishmania that cause diseases in humans and 12 species that infect animals. In the Americas, main species involved in cutaneous leishmaniasis in pets are Leishmania (Viannia) braziliensis, Leishmania (Leishmania) amazonensis, and, in the Old World, the species Leishmania infantum. ${ }^{1,2,3}$ There are many records of cases of cutaneous leishmaniasis in domestic cats and dogs, but as there is no scientific evidence that these animals are natural hosts of this parasite, they are still considered accidental reservoirs. ${ }^{1,4,5}$
Leishmaniasis in domestic animals has a higher incidence in Europe and South America. The number of cases of the disease in domestic animals is increasing, which values the diagnosis to confirm the disease and prevent its spread. Usually, diagnosis of leishmaniasis in humans and animals consists of clinical, epidemiological and laboratory tests. Laboratory tests recommended for the diagnosis of cutaneous leishmaniasis are: parasitological (direct collection of lesion material), immunological (antibody, antigen or cellular immune response tests), and molecular, such as polymerase chain reaction (PCR), among others. . $^{1,2,3,6}$

In Brazil, seropositive and/or parasitological positive are euthanized based on Resolution No. 714 of June 20th, 2002, from the Federal Council of Veterinary Medicine, which sets forth the procedures and methods of euthanasia in animals, among other provisions. This practice is criticized by the pet owners, some veterinarians and researchers. In some countries, such as 
Brazil, there are other recommendations as control of reservoirs, diagnosis and measures to prevent contamination of healthy dogs. ${ }^{7}$

In 2011, Bill No. 1738/11 was proposed in Brazil, which recommends not to euthanize animals with confirmed leishmaniasis. Euthanasia of animals carrying the disease would be the best way from a health point of view, but the costs with capture, tests and euthanasia of the animals could be reversed to combat the vectors that transmit the disease. ${ }^{8}$

Epidemiology, immunopathogenesis and laboratory diagnosis of leishmaniasis (cutaneous and visceral) in domestic animals have been widely studied in several regions of the world. However, most of the studies address methodologies for diagnosis of canine visceral leishmaniasis and just a few discusses cutaneous and mucocutaneous forms. Furthermore, diagnostic techniques vary between countries around the world, which can change the sensitivity, specificity and efficacy of the tests. ${ }^{2,9-17}$ Therefore, we propose this review with the objective to identify and characterize laboratory diagnostic methods used for the detection of cutaneous leishmaniasis in domestic dogs and cats in the Americas in order to analyze the sensitivity and specificity of the tests and indicate the most efficient ones, which should be used for the detection and monitoring of leishmaniasis in these animals.

\section{METHODS}

This is a systematic review, in which the types of eligible studies were original articles, master dissertations, doctoral theses and book chapters published in the last five years and available. Only articles in Portuguese, English and Spanish were considered for the analysis.

\section{Search strategy}

Search strategy in PubMed (US National Library of Medicine) consisted in using MeSH database for the terms "leishmaniasis", "cutaneous leishmaniasis", "mucocutaneous leishmaniasis", "diffuse cutaneous leishmaniasis", "Leishmania", "sensitivity and specificity", "animals", "diagnosis", "cat diseases", "cats", "dog diseases", "dogs". We also searched these terms and free terms in LILACS (Latin American and Caribbean Health Sciences Information Center), ISI Web of Science and SciELO database. Terms used in LILACS were: leishmaniasis, Leishmania, and diagnostic sensitivity and specificity.

\section{Data extraction}

Data were collected from August to September 2013. The potentially relevant studies were selected by the analysis of abstracts. Copies of full text of all studies identified as potentially relevant were retrieved. From
254 potential studies, 10 on cutaneous leishmaniasis in domestic animals of the Americas were selected. The remaining articles addressed visceral leishmaniasis, leishmaniasis in the Old World, leishmaniasis in humans, or they were literature reviews. Doctoral theses, master dissertations or book chapterswere not found.

\section{RESULTS AND DISCUSSION}

We analyzed 10 articles, seven on leishmaniasis in dogs, two on leishmaniasis in cats and one on both. ${ }^{10,11,13,18-24}$ Laboratory tests most commonly used in the Americas for the diagnosis of cutaneous leishmaniasis in these animals were: detection of anti-Leishmania antibodies by indirect immunofluorescence (IIF) and enzyme immunoassay (ELISA), antigens research using Western blot technique and molecular techniques such as polymerase chain reaction (PCR) (Tables 1 and 2).

In Brazil and Mexico, the most widely used tests for the diagnosis of canine cutaneous leishmaniasis are the direct test of the lesion material, IIF, ELISA, PCR and culture (Tables 1 and 2). Of these, IIF testing and enzyme immunoassay were those with higher reactivity when animal blood was used, being considered the most sensitive for the diagnosis of leishmaniasis in dogs. According to the Ministry of Health (BRAZIL, 2007), ${ }^{1}$ on cutaneous leishmaniasis, the tests of choice for diagnosis in dogs are direct examination and serological (IIF and ELISA).

Longoni et al $(2011)^{10}$ used Fe-SODe (iron superoxide dismutase) and $\mathrm{H}$ (total extract of Leishmania culture) antigenic fractions for the reaction of enzyme immunoassay and Western blot. These fractions were extracted and purified from parasites culture of L.mexicana, L. braziliensis and L. panamensis species. Of the $70 \mathrm{dogs}$, only four $(2.8 \%)$ were positive in the ELISA H-fraction, one for L. mexicana, and 3 for L. braziliensis. Fe-SODe ELISA-fraction was positive in 37 animals (25.9\%), identifying mainly L. mexicana and L. braziliensis, and just a few L. panamensis. Researchers also used Fe-SODe fraction in the research for the presence of antibodies by Western blot method, in which they achieved $33(47.1 \%)$ positive results for L. mexicana and $30(42.9 \%)$ for L. braziliensis. No sample was tested in Western blot for L. panamensis, because the enzyme immunoassay didn't show a good sensitivity.

Lópes-Céspedes et al (2012) ${ }^{22}$ used $\mathrm{H}$ and FeSODe fractions of L.mexicana, L. braziliensis and $L$. infantum parasite cultures for serological testing by enzyme immunoassay and Western blot technique, similar to Longoni et al (2011) ${ }^{10}$. The study analyzed samples from 412 dogs; ELISA-H had low sensitivity, and Fe-SODe-ELISA and Western blot Fe-SODe were more sensitive to all species investigated. Positivity for L.braziliensis was $7.5 \%$, for L. mexicana was $20.6 \%$, and 
TABLE 1: Characteristics of studies included in the review on leishmaniasis in domestic dogs

\begin{tabular}{|c|c|c|c|c|c|}
\hline Study & Country & Animals (n) & $\begin{array}{l}\text { Leishmania } \\
\text { species }\end{array}$ & Sample / Diagnostic Test & Test reactivity \\
\hline & & & & Lesion material/ direct test & Positive \\
\hline \multirow{4}{*}{$\begin{array}{l}\text { Cavalcanti } \\
\text { et al, } 2012^{18}\end{array}$} & \multirow[t]{4}{*}{ Brazil } & \multirow[t]{4}{*}{1} & \multirow{4}{*}{ L. infantum } & Blood/culture & Reagent \\
\hline & & & & $\mathrm{PCR}^{*}$ & Positive \\
\hline & & & & ELISA** & Title 640 \\
\hline & & & & Lesion material/Histological & Positive in one animal \\
\hline \multirow[t]{2}{*}{$\begin{array}{l}\text { Figueiredo } \\
\text { et al, } 2009^{19}\end{array}$} & \multirow[t]{2}{*}{ Brazil } & \multirow[t]{2}{*}{177} & \multirow[t]{2}{*}{ L. braziliensis } & Blood/ IIF*** & $\begin{array}{l}\text { Reactivity of } 10 \% \\
\text { (titles of } 40 \text { to } 320 \text { ) }\end{array}$ \\
\hline & & & & ELISA & Reactivity in $10.7 \%$ \\
\hline \multirow{3}{*}{$\begin{array}{l}\text { Heusser-Junior } \\
\text { et al, } 2010^{20}\end{array}$} & \multirow[t]{3}{*}{ Brazil } & \multirow[t]{3}{*}{275} & \multirow[t]{3}{*}{ L. (V.) braziliensis } & Lesion material/ direct test & Negative \\
\hline & & & & Blood/IIF & $1.1 \%$ (3 dogs) \\
\hline & & & & ELISA & $1.4 \%$ (4 dogs) \\
\hline \multirow{10}{*}{$\begin{array}{l}\text { Massunari, } \\
\text { et al, } 2009^{11}\end{array}$} & \multirow{8}{*}{ Brazil } & \multirow{8}{*}{146} & \multirow{8}{*}{ L. $(V)$ braziliensis } & Cellular / intradermal test & $1.8 \%$ (5 dogs) \\
\hline & & & & & Negative \\
\hline & & & & & Negative \\
\hline & & & & Lesion material/ direct test & $17.1 \%$ (25 animals) \\
\hline & & & & PCR & 2 dogs \\
\hline & & & & Blood/IIF & Negative \\
\hline & & & & PCR & \\
\hline & & & & Culture & \\
\hline & \multirow{4}{*}{ Brazil } & \multirow{4}{*}{31} & \multirow{4}{*}{ L. braziliensis } & Bone marrow/culture & Negative \\
\hline & & & & PCR & Negative \\
\hline \multirow{2}{*}{$\begin{array}{l}\text { Soccol } \\
\text { et al, } 2009^{21}\end{array}$} & & & & Tissue / Histological & Negative \\
\hline & & & & Blood/ELISA & $29 \%$ (9 animals) \\
\hline
\end{tabular}

${ }^{*}$ PCR: polymerase chain reaction; ${ }^{* *}$ ELISA: enzyme immunoassay; ${ }^{* * *}$ IIF: indirect immunofluorescence.

TABLE 2: Characteristics of articles included in the review of cutaneous leishmaniasis in domestic dogs, except laboratory results

\begin{tabular}{|c|c|c|c|c|}
\hline Study & Country & Animals (n) & Leishmania species & Sample / Diagnostic Test \\
\hline Longoni et al, $2011^{10}$ & Mexico & 70 & $\begin{array}{l}\text { L. mexicana } \\
\text { L. braziliensis } \\
\text { L. panamensis }\end{array}$ & $\begin{array}{l}\text { Blood/ELISA** } \\
\text { Western Blot }\end{array}$ \\
\hline Lópes-Céspedes et al, $2012^{22}$ & Mexico & 412 & $\begin{array}{l}\text { L. mexicana } \\
\text { L. braziliensis } \\
\text { L infantum }\end{array}$ & $\begin{array}{l}\text { Blood/ELISA ** } \\
\text { Western Blot } \\
\text { Culture }\end{array}$ \\
\hline Oliveira, et al, $2011^{23}$ & Brazil & 26 & L. $(V$.$) braziliensis$ & $\begin{array}{l}\text { Lesion material/ direct test } \\
\text { Blood/PCR }\end{array}$ \\
\hline
\end{tabular}

"PCR: polymerase chain reaction; ${ }^{* *}$ ELISA: enzyme immunoassay. 
for L.infantum was $6.1 \%$. The concordance of ELISA and Western blot using Fe-SODe fraction was greater than $84 \%$, reaching up to $99 \%$.

Use of antigenic Fe-SODe fraction based on Western blot is an optimal method for the detection of both feline and canine leishmaniasis. ${ }^{10,13,22}$

Oliveira et al $(2011)^{23}$, analyzed 26 samples from different regions of northwestern Paraná (Brazil): collection of lesion material from dogs for direct research and PCR was performed in eight, and blood from 18 animals was collected for PCR. Researchers tested the following primers: MP34-MP1L (best performance), B1-B2, LU5A-LB3C, LBF1-LBR1 and 13A-13B. For the lesion material, MP34-MP1L primer had $100 \%$ positivity and, for the blood, the positivity was $83.3 \%$. In the direct test, no sample was positive.

In Brazil and USA, tests for the diagnosis of leishmaniasis in cats were histopathological examination of the lesion, IIF, ELISA and PCR. As with dogs, the test that showed greater positivity in detection of leishmaniasis was enzyme immunoassay (Table 3).

Longoni et al (2012) ${ }^{13}$, using antigenic fractions (H and Fe-SODe) of cultures of L. mexicana, L. braziliensis and L. Infantum, investigated the presence of antibodies in the serum of cats using ELISA and Western blot techniques. Samples from 96 cats were analyzed in ELISA-H test, $13.68 \%$ were positive for L. infantum, $5.26 \%$ for L. braziliensis and only one sample was positive for L. mexicana. In ELISA Fe-SODe, positivity was higher $(22.10 \%)$ for $L$. infantum, reaching $10.25 \%$ for $L$. mexicana and $11.57 \%$ for L. braziliensis. In Western blot Fe-SODe test, $10.5 \%$ of the samples were positive for both L. mexicana and L. braziliensis, and $20 \%$ were positive for L. infantum.

Regarding testing and Leishmania species investigated in the selected studies in this review, in Brazil, most studies performed the research for antibodies or L. braziliensis antigens in both dogs and cats. This can be justified, since according to the Ministry of Health ${ }^{1}$, the main species causing the disease in this country is L. braziliensis. In the study of Longoni et al (2011) ${ }^{10}$, in the region of Tulum (Mexico), the most present specie was L. mexicana. On the other hand, in the region of Celestu'n (Mexico), it was reported more cases of infection with L. braziliensis. Lópes-Céspedes et al (2012) $)^{22}$ and Oliveira et al (2011) $)^{23}$ detected a higher number of infections caused by L. braziliensis.

Of the 10 studies analyzed in this review, only two assessed the sensitivity and specificity of the methods used. Few studies have used these quality parameters, which are important since they show the test's ability to detect truly positive and negative cases, excluding possible false positives and/or false negatives. ${ }^{25}$

In the study of Lópes-Céspedes et al(2012), for dogs, the sensitivity obtained by ELISA and Western blot Fe-SODe was $96.2 \%$ for L. braziliensis and 100\% for L. infantum and L. mexicana. ${ }^{22}$ Specificity was above 99\% for all species. In the study of Longoni et al (2012), for cats, the sensitivity of ELISA and Western blot using Fe-SODe fraction was $100 \%$, with specificity between $97 \%$ and $100 \%$, a positive predictive value between $91 \%$ and $100 \%$, and a negative predictive value of $100 \% .^{13}$

The studies that used more than one method for the diagnosis of leishmaniasis showed high concordance between tests, and the conduction of more than one method supports a more accurate and secure diagnosis of leishmaniasis. A study by Oswaldo Cruz Foundation (Fiocruz), in Brazil, suggested that the diagnosis of canine visceral leishmaniasis is most effective when used in combined tests. Thus, there is a decrease in false negative results as well as false positives. ${ }^{26}$

Brito (1999), in Pernambuco, using samples from humans, compared the sensitivity and specificity of IIF and ELISA tests with Western blot containing significant antigen of L.braziliensis. ${ }^{27}$ IIF and ELISA techniques presented a sensitivity of $51.7 \%$ and $62.1 \%$, and specificity of $78.6 \%$ and $71.4 \%$, respectively. In this case it was not observed difference between the methods. However, comparing it with the results of Western blot, sensitivity was $90.9 \%$ and specificity was $100 \%$, higher than IIF and ELISA. This study showed

TABLE 3: Characteristics of articles included in the review of cutaneous leishmaniasis in domestic cats

\begin{tabular}{llllll}
\hline Study & Country & Animals $(\mathrm{n})$ & $\begin{array}{l}\text { Leishmania } \\
\text { species }\end{array}$ & $\begin{array}{l}\text { Sample / } \\
\text { Diagnostic Test }\end{array}$ & Test reactivity \\
\hline Figueiredo, et al 200919 & Brazil & 43 & L. braziliensis & $\begin{array}{l}\text { Lesion material/Histological } \\
\text { Blood/IIF*** } \\
\text { ELISA }^{* *}\end{array}$ & $\begin{array}{l}\text { Negative } \\
\text { Non-reagent 2.4\% }\end{array}$ \\
Trainoret al 201024 & USA & 8 & $\begin{array}{l}\text { L. mexicana } \\
\text { amazonensis }\end{array}$ & $\begin{array}{l}\text { Lesion material/Histological } \\
\text { PCR }^{*}\end{array}$ & $\begin{array}{l}\text { Negative } \\
62.5 \%(5)\end{array}$ \\
\hline
\end{tabular}

* PCR: polymerase chain reaction; ** ELISA: enzyme immunoassay; *** IIF: indirect immunofluorescence. 
that the use of antigenic fractions to research the presence of antibodies by Western blot technique is much more sensitive for the detection of leishmaniasis.

\section{CONCLUSION}

The most used diagnostic methods to detect canine and feline cutaneous leishmaniasis are indirect immunofluorescence (IIF), enzyme immunoassay, polymerase chain reaction (PCR), direct tests of the lesion material, and Western blot. Western blot technique from purified Fe-SODe fraction showed satisfactory results, with high sensitivity, specificity and efficacy for the detection of this disease in animals. We suggest that more than one technique should be used for detection of feline and canine cutaneous leishmaniasis and that Western blot technique using Fe-SODe fraction should be widely used.

\section{REFERENCES}

1. Brasil. Ministério da Saúde. Secretaria de Vigilância em Saúde. Departamento de Vigilância Epidemiológica. Manual de Vigilância da Leishmaniose Tegumentar Americana. 2. ed. - Brasília : Editora do Ministério da Saúde, 2007. 182 p. - (Série A. Normas e Manuais Técnicos).

2. Dantas-Torres F. Canine leishmaniosis in South America. Parasit Vectors 2009;2:S1:1-8.

3. Dantas-Torres F, de Paiva-Cavalcanti M, Figueredo LA, Melo MF, da Silva FJ, da Silva $A L$, et al. Cutaneous and visceral leishmaniasis in dogs from a rura community in northeastern Brazil. Vet Parasitol. 2010;170:313-7.

4. Maroli M, Pennisi MG, Di Muccio T, Khoury C, Gradoni L, Gramiccia M.Infection of sandflies by a cat naturally infected with Leishmania infantum. Vet Parasitol. 2007;145:357-60.

5. Maroli M, Jalouk L, Al Ahmed M, Bianchi R, Bongiorno G, Khoury C, al. Aspects of the bionomics of Phlebotomus sergenti sandflies from an endemic area of anthroponotic cutaneous leishmaniasis in Aleppo Governorate, Syria. Med Vet Entomol. 2009;23:148-54

6. Solano-Gallego L, Koutinas A, Miró G, Cardoso L, Pennisi MG, Ferrer L, et al. Directions for the diagnosis, clinical staging, treatment and prevention of canine leishmaniosis. Vet Parasitol. 2009:165:1-18.

7. Conselho Federal de Medicina Veterinária (Brasil). Resolução № 714, de 20 de Junho de 2002. Dispõe sobre procedimentos e métodos de eutanásia em animais, e dá outras providências. Diário Oficial da União 21 jun 2002; Seção 1.

8. Brasil. Projeto de Lei $n^{0} 1738 / 11$, de 30 de Junho de 2011. Dispõe sobre a Política Nacional de Vacinação contra a Leishmaniose animal.

9. Lonardoni MV, Silveira TG, Alves WA, Maia-Elkhoury AN, Membrive UA, MembriveNA, et al. Leishmaniose tegumentar americana humana e canina no Município de Mariluz, Estado do Paraná, Brasil. Cad Saude Publica. 2006;22:2713-6.

10. Longoni SS, Marín C, Sauri-Arceo CH, López-Cespedes A, Rodríguez-Vivas $\mathrm{Rl}$, Villegas $\mathrm{N}$, et al. An iron-superoxide dismutase antigen-based serologica screening of dogs indicates their potential role in the transmission of cutaneous leishmaniasis and trypanosomiasis in Yucatan, Mexico. Vector Borne Zoonotic Dis. $2011 ; 11: 815-21$

11. Massunari GK, Voltarelli EM, Santos DR, Santos AR, Poiani LP, de Oliveira 0 , et at. A serological and molecular investigation of American cutaneous leishmaniasis in dogs, three years after an outbreak in the Northwest of Paraná State, Brazil. Cad Saude Publica. 2009;25:97-104.

12. Morales-Yuste M, Morillas-Márquez F, Díaz-Sáez V, Barón-López S, Acedo-Sánchez C, Martín-Sánchez J.Epidemiological implications of the use of various methods for the diagnosis of canine leishmaniasis in dogs with different characteristics and in differing prevalence scenarios. Parasitol Res. 2012;111:155-64.

13. Longoni SS, López-Cespedes A, Sánchez-Moreno M, Bolio-Gonzalez ME, SauriArceo $\mathrm{CH}$, Rodríguez-Vivas RI, et al. Detection of different Leishmania spp. And Trypanosoma cruzi antibodies in cats from the Yucatan Peninsula (Mexico) using an iron superoxide dismutase excreted as antigen. Comp Immunol Microbiol Infect Dis. 2012:35:469-76.

14. Solano-Gallego L, Rodríguez-Cortés A, Iniesta L, Quintana J, Pastor J, Espada Y, et al. Cross-sectional serosurvey of feline leishmaniasis in ecoregions around the Northwestern Mediterranean. Am J Trop Med Hyg. 2007;76:676-80

15. Nasereddin A, Salant $H$, Abdeen Z. Feline leishmaniasis in Jerusalem: serological investigation. Vet Parasitol. 2008;158:364-9.

16. Cardoso L, Lopes AP, Sherry K, Schallig H, Solano-Gallego L. Low prevalence of Leishmania infantum infection in cats from northern Portugal based on DAT and ELISA. Vet Parasitol. 2010:174:37-42.
17. Sherry K, Miró G, Trotta M, Miranda C, Montoya A, Espinosa C, et al. A serological and molecular study of Leishmania infantum infection in cats from the Island of Ibiza (Spain). Vector Borne Zoonotic Dis. 2011;11:239-45.

18. Cavalcanti A, Lobo R, Cupolillo E, Bustamante F, Porrozzi R. Canine cutaneous leishmaniasis caused by neotropical Leishmania infantum despite of systemic disease: A case report. Parasitol Int. 2012;61:738-40.

19. Figueiredo FB, Bonna IC, Nascimento LD, Costa Td, Baptista C, Pacheco TM, et al. Serological evaluation for detection of anti-Leishmania antibodies in dogs and cats in the district of Santa Rita de Cássia, municipality of Barra Mansa, State of Rio de Janeiro. Rev Soc Bras Med Trop. 2009;42:141-5

20. Heusser Júnior A, Bellato V, Souza AP, Moura AB, Sartor AA, Santos EG, et al. Canine tegumentar leishmaniasis in the town of Balneário Camboriú in the State of Santa Catarina. Rev Soc Bras Med Trop. 2010;43:713-8.

21. Soccol VT, de Castro EA, Schnell e Schühli G, de Carvalho Y, Marques E, Pereira Ede $F$, et al. A new focus of cutaneous leishmaniasis in the central area of Parana State, southern Brazil. Acta Trop. 2009;111:308-15.

22. López-Céspedes A, Longoni SS, Sauri-Arceo CH, Sánchez-Moreno $M$ Rodríguez-Vivas RI, Escobedo-Ortegón FJ, et al. Leishmania spp. epidemiology of canine leishmaniasis in the Yucatan Peninsula. ScientificWorldJournal. 2012;2012:945871

23. Oliveira DM, Lonardoni MV, Teodoro U, Silveira TG. Comparison of different primes for PCR-based diagnosis of cutaneous leishmaniasis. Braz J Infect Dis. 2011;15:204-10.

24. Trainor KE, Porter BF, Logan KS, Hoffman RJ, Snowden KF. Eight cases of feline cutaneous leishmaniasis in Texas. Vet Pathol. 2010;47:1076-81.

25. Soares JF, Siqueira AL. Introdução à Estatística Médica. Belo Horizonte: COOPMED, UFMG; 1999

26. Agencia.fiocruz.br[Internet]. Lourenço P. Testes para leishmaniose canina têm melhor eficácia se usados em conjunto. 2005. [acesso 25 fev. 2013]. Disponível em: http://www.agencia.fiocruz.br/testes-para-leishmaniose-canina-t\%C3\%AAmmelhor-efic\%C3\%A1cia-se-usados-em-conjunto.

27. Brito MEF. Desenvolvimento de um método diagnóstico para a leishmaniose tegumentar americana com base em Western blot de frações antigênicas de Leishmania braziliensis. Rev Soc Bras Med Trop. 1999;32:313-4

How to cite this article:Demarchi IG, Trevisan DAC. Diagnostic methods to cutaneous leishmaniasis detection in domestic dogs and cats. An Bras Dermatol. 2015;90(6):868-72. 